\title{
Detection of apoptosis in pemphigus vulgaris by TUNEL technique*
}

\author{
Juan Carlos Cuevas-Gonzalez ${ }^{1}$ \\ Francisco Javier García-Vázquez ${ }^{3,4}$
}

\author{
Maria Elisa Vega-Memíje $e^{2}$ \\ Marco António Aguilar-Urbano ${ }^{4}$
}

DOI: http:/ / dx.doi.org/10.1590/abd1806-4841.20164598

\begin{abstract}
BAcKground: Pemphigus is part of a group of blistering diseases that affect the skin and mucous membranes. Based on its autoimmune origin, autoantibodies develop in pemphigus that are directed toward cell surface components of keratinocytes. However, some data cannot be explained, such as the lack of a relationship between autoantibody levels and the severity of clinical manifestations, treatment resistance, the presence of inflammatory infiltrates and the potential occurrence of apoptosis as determinants of vesicle formation.

OвJестіVE: To examine the presence of apoptosis in pemphigus vulgaris by TUNEL technique.

Methods: In this cross-sectional study, we selected 15 paraffin-embedded tissues from subjects who were diagnosed with pemphigus vulgaris by hematoxylin and eosin staining. The samples were subjected to TUNEL assay and examined under an Olympus BX61 fluorescence microscope. Positivity was categorized dichotomously, and the statistical analysis was performed using the $\mathrm{X} 2$ test.

REsults: Positivity was observed in basal layer cells in 14 (93.3\%) cases. In 13 (86.7\%) of the positive cases, we noted espinosum and granular layers that formed the blister roof, and in 12 cases (80\%), positive acantholytic cells were observed.

CONCLUSIONS: TUNEL positivity was observed in pemphigus vulgaris, implicating apoptosis in the pathophysiology of this condition, which can help guide the development of apoptotic blockers as therapeutics.
\end{abstract}

Keywords: Apoptosis; Autoimmune diseases; Pemphigus; TUNEL technique

\section{INTRODUCTION}

Pemphigus is part of a group of blistering diseases that affect the skin and mucous membranes, involving autoantibodies that are directed against cell surface components of keratinocytes, causing acantholysis and blistering. ${ }^{1-3}$

The etiology of pemphigus is considered autoimmune in nature, based on the associated autoantibody production and reservoirs of IgG and IgA against desmosomes components (desmoglein 3 and 1). ${ }^{5}$ Depending on these features, there can be 2 principal types of pemphigus: pemphigus vulgaris (PV), with the vegetans variant (PVe); and pemphigus foliaceus
(PF). Other, less common types include paraneoplastic pemphigus, caused by drugs and IgA. ${ }^{6}$

PV is the most common form of pemphigus and develops preferentially in females between the fourth and sixth decades of life; in Mexico, PV occurs before the age of $40 .^{7}$ Although the clinical features dictate its diagnosis, it must be supported by histopathological findings, wherein intraepidermal and suprabasal acantholytic blisters are observed. By direct immunofluorescence, IgG and C3 deposits are seen; and through indirect immunofluorescence, antiepithelium antibodies react against the intercellular

Received on 30.03.2015.

Approved by the Advisory Board and accepted for publication on 03.08.2015.

Work performed at the Hospital General Dr. Manuel Gea Gonzalez - Mexico City, Mexico

Financial Support: None.

Conflict of Interest: None.

Juarez University of the State of Durango - Durango (Dgo), Mexico.

Hospital General "Dr. Manuel Gea González" - Mexico City, Mexico.

National Institute of Pediatrics - Mexico City, Mexico.

Southern Associated Pathologists "Specialists in Pathology Laboratories" - Mexico City, Mexico.

(C)2016 by Anais Brasileiros de Dermatologia 
surface of keratinocytes (desmoglein 3). ${ }^{8}$

In vitro studies have demonstrated the involvement of IL1, IL6, and TNF alpha by macrophages, as well as the participation of NK cells and neutrophils, suggesting that TNF alpha induces and exacerbates PV.

Several studies have implicated NSAIDs, penicillin, pyrazolone, and antihypertensive agents as triggers of the disease. Pemphigus has also been associated with contact allergens, viruses, hormones, emotional stress ${ }^{1,7}$ and exposure to gardening materials, pesticides, and metals. ${ }^{9}$

Although the immunopathogenesis of pemphigus has been detailed, the existing data do not explain the lack of a relationship between autoantibody levels and the severity of clinical manifestations, treatment resistance, the presence of inflammatory infiltrate, and apoptosis, as determinants of vesicle formation. ${ }^{10}$

The term apoptolysis was recently coined to better understand cell death and examine the pathophysiology of PV, comprising 5 steps:

1. Union between antibody and antigen.

2. Activation of EGF, Src, mTOR, and p38 MAPK, and elevation of intracellular calcium on receptor-mediated activation of caspases.

3. Basal cell contraction.

4. Cell division protein.

5. Cell damage and cell death (apoptosis and acantholysis). ${ }^{11}$

This wide range of inductive factors may be involved in the pathophysiology of apoptosis in pemphigus vulgaris. If this hypothesis is supported by TUNEL assay, apoptosis-blocking agents can be used to treat PV.

\section{METHODS}

In this cross-sectional study, we selected 15 paraffin-embedded tissues with a confirmed diagnosis of PV by hematoxylin and eosin staining, and 15 controls [skin without histopathological alteration (normal variants)]. Pemphigus vulgaris (patients) and tissue controls were between the third and fourth decades of life.

One-micron-thick sections were cut and processed by TUNEL assay (transferase-mediated dUTP nick end-labeling).

Deparaffinized and rehydrated tissue sections were subjected to antigen unmasking with $0.1 \mathrm{M}$ sodium citrate, $\mathrm{pH}$ 6.2; then, 100 ul DNAse-free proteinase $\mathrm{K}$ was placed on each slide for 30 minutes. Next, 50 ul of TACS nuclease reaction mix (streptavidin-HRP solution) (Roche) and 500 ul diluent (streptavidin) were added by capillary action and incubated for 30 minutes.

Subsequently, $450 \mathrm{ul}$ of enzyme solution and 50 $\mathrm{ul}$ of fluorescein-labeled solution were prepared; $50 \mathrm{ul}$ of each reagent was then added to the 15 slides and incubated for 60 minutes at $37^{\circ} \mathrm{C}$ in a moist, dark chamber. Counterstaining was performed with Evans blue, and a coverslip was placed, with fluorescent mounting medium (Dako Fluorescent Mounting Medium, Cat. S3023, DakoCytomation). All washes between each step were performed with TBS.

Reactions were examined under an Olympus BX61 fluorescence microscope. Positivity was categorized dichotomously, and the results were analyzed by $\mathrm{X} 2$ test.

\section{RESULTS}

Fifteen paraffin-embedded tissue blocks with a diagnosis of PV and sufficient material were selected and included.

Positivity in the TUNEL assay was observed in basal layer cells in $14(93.3 \%)$ cases; 1 case showed no expression in this stratum. In 13 positive cases $(86.7 \%)$, we noted a blister roof formed by the squamous and granular layers, while 12 cases $(80 \%)$ were positive for acantholytic cells (Figures 1 and 2).

With respect to the controls, the TUNEL technique was positive in $12 / 15(80 \%)$ of the tissues, exclusively in the granular layer.

We found no significant difference in positivity in the basal layer regarding the other layers or acantholytic cells $\left(X^{2}=.685, p=.685 ; X^{2}=.268, p=.605\right)$.
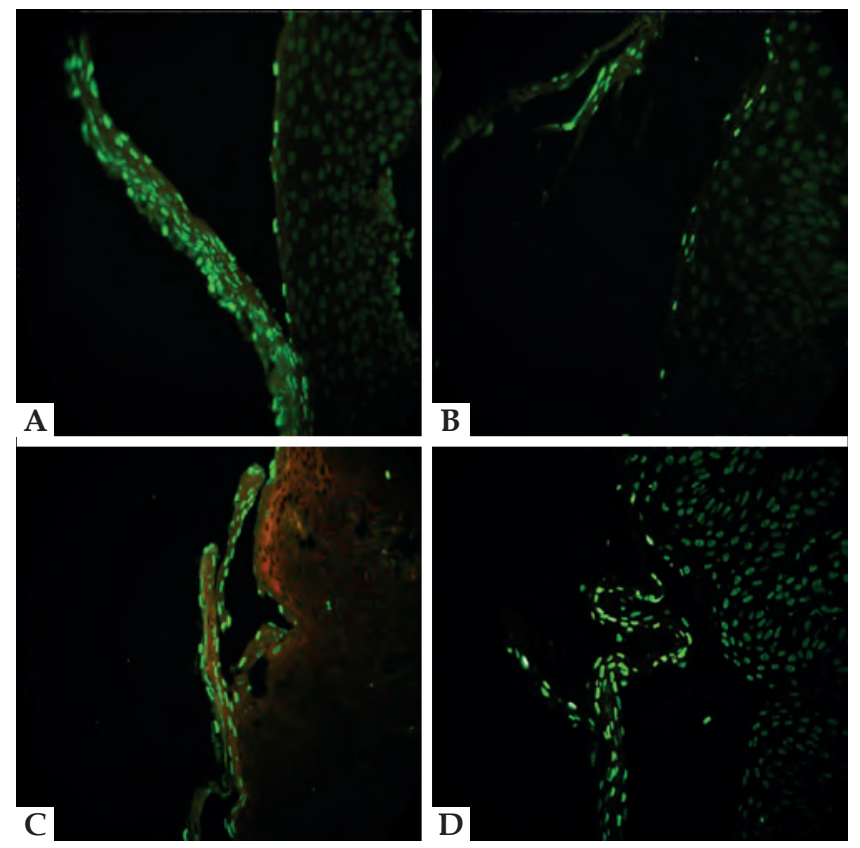

FIgURE 1: A. TUNEL (400x) positivity in cells that form the roof of the blister. B. Labeled cells arranged in a headstone pattern in the basal layer. C. Positivity in cells that constitute the blister (roof, basal layer cells and acantholytic cells). D. In some cases, adjacent cells were also labeled 

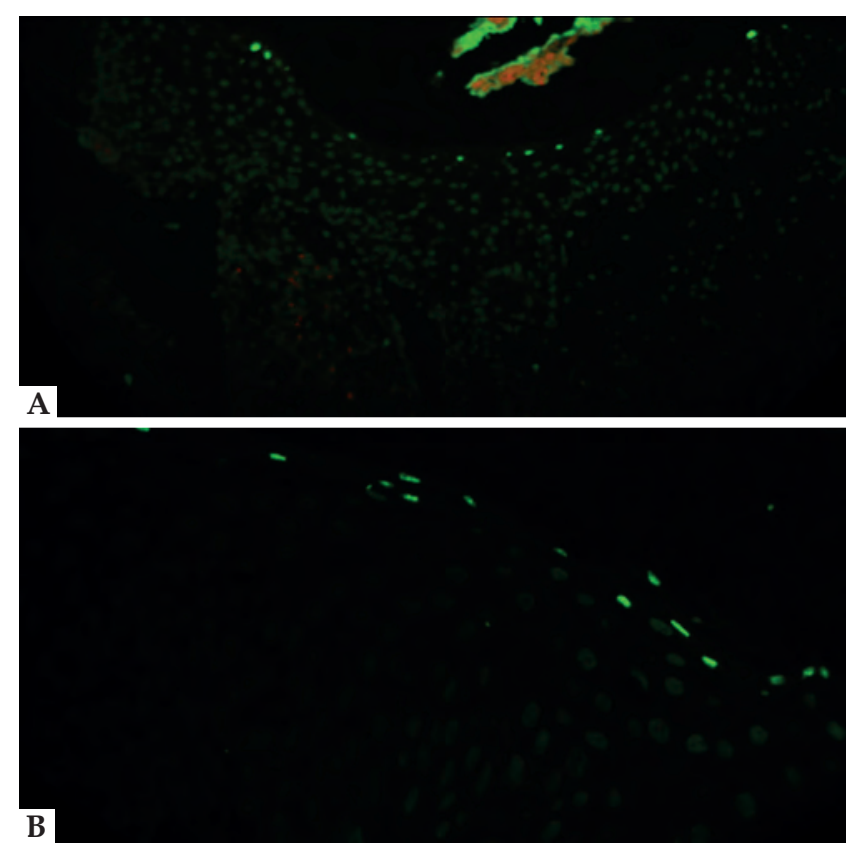

FigUre 2: A and B (400x). TUNEL results of suprabasal blisters characteristic of pemphigus; positive cells correspond to basal cells, and cells adjacent to the vesicle show no reaction

\section{DISCUSSION}

Apoptosis is defined as programmed cell death, whereby series of enzymatic reactions are initiated when a cell starts to undergo apoptosis, provoking the disorganization of protein and subsequent damage to DNA. In the initial apoptosis sites, the integrity of the membrane is maintained, preventing intracellular components from being released, thus avoiding direct tissue damage. ${ }^{12}$

TUNEL is a useful method for detecting apoptosis, because during this event, nuclear endonuclease-digested genomic DNA is fragmented into oligonucleosomes (180-200 base pairs), allowing DNA fragments to be identified by the catalytic addition of 16-dUTP to the free ends by terminal deoxynucleotidyl transferase (TdT). ${ }^{13}$

The extrinsic pathway of apoptosis involves the death receptors type 1 TNF and Fas (CD95), in addition to their ligands TNF and Fas ligand (FasL), respectively. These receptors harbor an intracellular death domain that recruits the adapter proteins TNF (TRADD) and Fas-associated domain (FADD), as well as cysteine proteases, such as caspases-caspase 8 is an apoptotic initiator caspase. ${ }^{14}$ A previous study reported the robust expression of Fas and Fas L in keratinocytes in the epidermis of pemphigus lesions (a mean of over 50 and up to 100 positive cells per field at $400 x$, respectively). ${ }^{15}$

Deyhimi and Tavakoly studied 25 pemphigus vulgaris tissue samples by TUNEL and noted positivity in $100 \%$ of cases, in cells arranged in a headstone pattern in the basal layer and in the cells that formed the blister roof, with varying intensities. In $76 \%$ of cases, acantholytic cells showed positivity of above $75 \%$. Furthermore, $12 \%$ had $26-50 \%$ positivity, and 1 case (4 had $51-75 \%$ reactivity. ${ }^{16}$

Through TUNEL, Pacheco et al. identified positive cells that were adjacent to the blister. ${ }^{15}$ The results we obtained using TUNEL are consistent with those of Deyhimi and Tavakolyal, and Pacheco et al. - positivity was observed in cells in the basal layer in 14 (93.3\%) cases, while $13(86.7 \%)$ cases showed reactivity in cells forming the roof of the blister, and 12 (80\%) samples showed uptake in acantholytic cells.

Thus, the activation of apoptosis in PV supports our hypothesis, while our findings are in agreement with Gil et al., who reported that apoptosis is involved in PV lesions, reflected by: DNA fragmentation; increased expression of proapoptotic molecules, such as Fas Fas L, Bax, and p53; and the loss of antiapoptotic molecules, such as BCL2. ${ }^{17}$ Notably, we observed apoptosis in areas of blister formation, comprising basal cells, which surrounded the blister, and acantholytic cells. Thus, apoptotic mechanisms are involved on such sites, and we conclude that programmed cell death and blister formation mediate the persistence of PV.

In 2004, Gilhar et al. reported that the human epidermis shows morphological changes with age, and they found that in young epidermis are limited to the granular layer, unlike aged epidermis, TUNEL-positive cells were found in the granular layer and scattered throughout the whole epidermis associated with apoptosis. ${ }^{18}$

We performed the microscopic evaluation with H\&E on our cases and controls, and we found no morphological alterations linked to age; the TUNEL technique conducted in the cases revealed that positivity was present in the granular layer, acantholytic cells, basal layer (the cells arranged in a headstone pattern), and in some cases throughout the whole epidermis, which supports our findings that apoptosis increases in PV. Tissue without histopathological alterations were positive to the TUNEL technique; this positivity was present in the granular layer, indicating terminal differentiation.

We agree with Deyhimi et al. that the process of apoptosis may exacerbate or speed up bulla formation. ${ }^{16}$ 
In a review of the immunopathology of $\mathrm{PV}$, Chiapa and Becker examined studies that reported synergism between PV antibodies, FasL, and TNF alpha in reducing cell size and regenerating acantholysis in keratinocytes in vitro, suggesting a particular sequence of cell damage and interactions between mechanisms of cell generation. ${ }^{19}$

\section{CONCLUSION}

TUNEL positivity was observed in PV, implicating apoptosis in the pathophysiology of this condition, which can help guide the development of apoptotic blockers as therapeutics.

\section{REFERENCES}

1. Castellanos Î́niguez AA, Guevara Gutiérrez E. Pénfigo vulgar. Dermatología Rev Mex. 2011; 55:73-83.

2. Vega-Memije ME, Sáez de Ocariz-Gutiérrez MM, Cortés-Franco R, DomínguezSoto L, Granados-Arriola J. Análisis de HLA-DR en pacientes mexicanos con pénfigo. Gac Méd Méx. 2001;137:535-40.

3. Mascaró JM Jr, España A, Liu Z, Ding X, Swartz SJ, Fairley JA, et al. Mechanisms of acantholysis in pemphigus vulgaris: role of IgG valence. Clin Immunol Immunopathol. 1997;85:90-6.

4. Sanchez J, Garcia A. Pénfigo. Actas Dermosifiliogr. 2005; 96:329-56.

5. Flores G, Culton DA, Prisayanh P, Qaqish BF, James K, Maldonado M, et al. IgG autoantibody response against keratinocyte cadherins in endemic pemphigus foliaceus (fogo selvagem). J Invest Dermatol. 2012;132:2573-80.

6. Aldama A, Correa J, Rivelli V, Mendoza G. Tipos y variantes de Pénfigo en el Hospital Nacional de Paraguay. Revisión de 70 casos. Med Cutan Iber Lat Am. 2000; 28:242-7.

7. Cenetec.salud.gob.mx [Internet]. Guía de Prática Clínica. Abordaje terapéutico dermatológico ambulatorio del pénfigo vulgar en adultos. México: Instituto Mexicano del Seguro Social, 2013. [cited 2015 Feb 10]. Available from: http:// www.cenetec.salud.gob.mx/descargas/gpc/CatalogoMaestro/IMSS_593_13_ PENFIGOVULGAR/593GER.pdf

8. Chanussot C, Vega ME, Mosqueda A, Vallejo B, Barrezueta S, Hernandez L et al. Pénfigo vulgar en una niña de 14 años. Med Cutan Iber Lat Am. 2007; 35:285-9.

9. Valencia 0J, Velásquez M. Inmunopatogenia del pénfigo vulgar y el pénfigo foliáceo. latreia. 2011;24:272 -86.

10. Oliveira ME, Culton DA, Prisayanh P, Qaqish BF, Diaz LA. E-cadherin autoantibody profile in patients with pemphigus vulgaris. Br J Dermatol. 2013;169:812-8.

11. Grando SA, Bystryn JC, Chernyavsky Al, Frusić-Zlotkin M, Gniadecki R, Lotti R, et al. Apoptolysis: a novel mechanism of skin blistering in pemphigus vulgaris linking the apoptotic pathways to basal cell shrinkage and suprabasal acantholysis. Exp Dermatol. 2009;18:764-70.

12. Navarrete C, Ibáñez C. Rol de la Apoptosis en la Fisiopatología del Lupus Eritematoso Sistémico. Rev Chil Reumatol. 2008;24:30-8.

13. Panizo A, Vega F. Estudio de la apoptosis mediante la técnica de TUNEL. Rev Esp Patol.1997; 30:243-5.

14. med.unne.edu.ar [Internet]. Sosa RD, Brandan N, Jeréz J. Apoptosis. Catedra de bioquímica-apoptosis. UNNE, 2012. [Cited 2015 Feb 28] . Available from: http:// med.unne.edu.ar/sitio/multimedia/imagenes/ckfinder/files/files/Carrera-Medicina/ BIOQUIMICA/apoptosis.pdf
15. Pacheco-Tovar MG, Avalos-Díaz E, Vega-Memije E, Bollain-y-Goytia JJ, LópezRobles E, Hojyo-Tomoka MT, et al. The final destiny of acantholitic cells in pemphigus is Fas mediated. J Eur Acad Dermatol Venereol. 2009;23:697-701.

16. Deyhimi P, Tavakoli P. Study of apoptosis in oral pemphigus vulgaris using immunohistochemical marker Bax and TUNEL technique. J Oral Pathol Med. 2013;42:409-14.

17. dspace.unav.es [Internet]. Gil, MP. Papel de la Fak en la acantólisis de pénfigo vulgar en un modelo murino. Tesis Doctoral. Universidad de Navarra, 2012. [cited 2015 Mar 02] . Available from: http://dspace.unav.es/dspace/ bitstream/10171/22532/1/Tesis\%20MPilar\%20Gil\%20S\%C3\%A1nchez.pdf

18. Gilhar A, Ullmann Y, Karry R, Shalaginov R, Assy B, Serafimovich S, et al. Ageing of human epidermis: the role of apoptosis, Fas and telomerase. Br J Dermatol. 2004; $150: 56-63$.

19. Chiapa M, Becker I. Pénfigo vulgar: una revisión de la inmunopatología Bioquimica. 2007;32:100-8.

\author{
MAILING ADDRESS: \\ Maria Elisa Veja-Memíje, MD. \\ Calzada de Tlalpan 4800 \\ Sección XVI \\ Delegación Tlalpan \\ México, D.F. C.P 14080 P \\ E-mail: elisavega50@gmail.com
}

How to cite this article: Cuevas-González JC, Vega-Memíje ME, García-Vazquez FJ, Aguilar-Urbano MA. Detection of apoptosis in pemphigus vulgaris by TUNEL technique. An Bras Dermatol. 2016;91(3):296-9. 